\title{
S-100 Protein-Immunoreactive Cells in the Lymph Node and Spleen of the Rat
}

\author{
Toshihiko Iwanaga, Tsuneo Fujita ${ }^{1}$, Toru Masuda and Yasuo Takahashi ${ }^{2}$ \\ Department of Anatomy (Prof. T. FujiTA), ${ }^{1}$ Niigata University School of Medicine and Department of \\ Neuropharmacology (Prof. Y. TAKAHASHI), ${ }^{2}$ Brain Research Institute, Niigata University, Niigata, \\ Japan
}

Received July 15, 1982

Summary. The present study deals with an immunocytochemical localization of S-100 protein in the rat lymph nodes and spleen. The immunoreactivity for S-100 was contained in the reticular cells within the germinal center. The immunoreactive cells possessed a scanty perinuclear cytoplasm and extended slender cytoplasmic processes among lymphocytes. No cell outside the germinal center showed any immunoreactivity to the anti-S-100 serum.

S-100 protein, one of the nervous system-specific proteins, was originally isolated by Moore (1965) from the central nervous system (CNS) of mammals. The S-100 is a soluble and membrane-bound protein with a molecular weight of about 21,000 (ZomzeLYNeURATH and WALKER, 1980); it possesses a specific ability to combine with $\mathrm{Ca}^{2+}$ (IsOBE and Oкuунма, 1978). Recent immunocytochemical studies have revealed that this protein is located primarily in the neuroglia. Astrocytes, oligodendrocytes and ependymal cells in the CNS have been reported to contain S-100 (LuDwin et al., 1976; Cocchia, 1981). Outside the CNS, the S-100 is present in Schwann cells of myelinated and unmyelinated peripheral nerves and in satellite cells of sensory and autonomic ganglia (Stefansson et al., 1982a) and adrenal medulla (Cocchia and Michetti, 1981). These cells have reasonably been categorized as glial cells in the peripheral nervous system. In addition, sustentacular cells which have been suspected to correspond to glial elements, such as the Müller cells in the retina (Kondo et al., unpublished), sustentacular cells in the carotid body (Kondo et al., 1982) and the inner bulb cells of lamellate terminal bodies (IwANAG A et al., 1982) are immunoreactive for S-100. It seems equivocal whether the stellate cells of the adenohypophysis whose S-100 immunoreactivity was reported by NaKajima et al. (1980) and Cocchia and Miani (1980) and also confirmed by us, are glial or non-glial in nature.

S-100 or like immunoreactants, on the other hand, were found to also exist in nonglial cells such as chondrocytes (STEFANSSON et al., 1982b), Langerhans cells of the human skin (Cocchia et al., 1981; NAKAJima et al., 1982a) and fat cells (NAKAJima et al., 1982c). Along with these cells, the present authors preliminarily recognized that certain cells of mesenchymal origin are reactive to anti-S-100 antisera (IwANAGA et al., unpublished). Thus, the S-100 may be able to become a marker substance of a series 
of cells in connective and lymphoid tissues, besides that of neuroglial elements. Precise categorization of these non-glial S-100-positive cells must be attained by recording and analysing individual positive cases in different tissues and animals. The present study deals with an immunocytochemical localization of the S-100 in the reticular cells of the rat lymph nodes and spleen.

\section{MATERIALS AND METHODS}

Adult Wistar rats (male, 250-300 g) were anesthetized with sodium pentobarbital (4 mg $/ 100 \mathrm{~g}$ ) and perfused through the heart with $4 \%$ paraformaldehyde in $0.1 \mathrm{M}$ phosphate buffer $\mathrm{pH}$ 7.4. The submaxillary and mesenteric lymph nodes and the spleen were removed, dissected and immersed in the fixative for $4 \mathrm{hr}$ at room temperature. After fixation, the specimens were rinsed in $0.1 \mathrm{M}$ phosphate buffer for several hours at $4^{\circ} \mathrm{C}$ and immersed overnight at $4^{\circ} \mathrm{C}$ in $30 \%$ sucrose solution. They were rapidly frozen in acetone-dry ice and cut at $10-20 \mu \mathrm{m}$ by a cryostat (Coldtome CM41, Sakura).

The cryostat sections were subjected to the peroxidase anti-peroxidase (PAP) method of STERNBERGER (1974). The anti-S-100 serum used in this study was raised in a rabbit by injections of a conjugate of S-100 purified from bovine brains with methylated bovine serum albumin. The sections were incubated for $3 \mathrm{hr}$ at room temperature with the antiserum at a dilution of $1: 1,000$.

For electron microscope observation some immunostained sections were post-fixed in $1 \% \mathrm{OsO}_{4}$ and embedded in Araldite according to routine procedures. Ultrathin sections, after being stained with uranyl acetate, were observed in a Hitachi HU 125 DS electron microscope.

Conventional staining controls as suggested by STERNBERGER (1974) were employed. In addition, the antiserum was incubated for $24 \mathrm{hr}$ at $4^{\circ} \mathrm{C}$ with the antigen $(20 \mu \mathrm{g}$ $\mathrm{S}-100 / \mathrm{ml}$ diluted antiserum) before the immunostaining.

\section{RESULTS AND DISCUSSION}

In the lymph nodes of rats, numerous reticular cells within the germinal center of lymph nodules showed a strong immunoreactivity to the anti-S-100 serum. The immunoreaction of the cells was inhibited by preincubation of the antiserum with the antigen (S-100 protein). Thick (10-20 $\mu \mathrm{m})$ cryostat sections revealed the dense meshwork formed by the long cytoplasmic processes of the immunostained cells (Fig. 1). Negative in reaction were the reticular cells outside the germinal center and in the circumferential reticulum consisting of a few layers of flattened reticular cells bordering the germinal center. In the spleen of the rat, the S-100-immunoreactivity was found also in the reticular cells restricted to the germinal center of the white pulp.

Observation of the immunostained cells by the electron microscope revealed their ultrastructural profiles. The peroxidase-labelled cells possessed a poor perinuclear cytoplasm and extended slender cytoplasmic processes which connected with those of adjacent cells (Fig. 2). Clear desmosome structures were found at the junctional sites (Fig. 3).

Our S-100-immunoreactive cells represent a specific type of reticular cell which is localized within the germinal center and has desmosomes. It has been proposed that the reticular cells in the germinal center are distinguishable from those outside of it in 




Fig. 1. Cryostat section $(20 \mu \mathrm{m})$ from the mesenteric lymph node of the rat. Most of the reticular cells within the germinal center showed strong immunoreactivity to the anti-S-100 serum. PAP method. $\times 350$

Fig. 2. Electron micrograph showing the immunoreactive reticular cells $(R)$ with the scanty perinuclear cytoplasm. Note the slender cytoplasmic processes among lymphocytes $(L) . \times 6,200$

Fig. 3. Desmosome structures (arrow) between two adjacent processes of the immunoreactive reticular cells. $\times 30,500$ 
ultrastructural and immunological aspects (Heusermann et al., 1980). Therefore, it is not unreasonable to propose that the reticular cells within the germinal center might possess a specific protein which is lacking in cells in other sites.

On the other hand, NAKAJIMA et al. (1982b) demonstrated in the human that the interdigitating cells which were distributed in the paracortical area of lymph nodes immunoreacted to his anti-S-100 serum and that there was no immunoreactive cell in the germinal center. In human materials we could also confirm this finding by Nakajima. The reason for this discrepancy in the types of the immunostained cells between the two species remains to be elucidated. Some biochemical studies have revealed that the S-100 consisted of several subunits (ZOMZELY-NEURATH and WaLKer, 1980).

The reticular cells containing immunoreactive S-100 represent a newly revealed member of the group of non-glial and S-100-positive cells which includes chondrocytes, fat cells and Langerhans cells of the skin. There is no inclusive explanation for this variety of cells sharing a specific protein, S-100. We can categorize the non-glial S100-positive cells as specialized fibroblasts. The intimate relation between fat cells and reticular cells has repeatedly been demonstrated. Especially in the bone marrow it has been established that the reticular cells may transform into fat cells (WeIss, 1980; KASHIMURA, 1982). However, the question as to why only the particular members of the fibroblastic cell line possess the S-100 or a like protein remains completely obscure.

It may be worthwhile to point out that the cells in question are presumably highly active in cell function. The fat cells are busily engaged in energy release and storage by metabolizing their fat; chondrocytes must possess an efficient metabolic mechanism as they are located in an extensive avascular matrix.

As to the reticular cells in the germinal center, they presumably have the important function of supporting and nursing lymphocytes while the latter proliferate and differentiate in the center. In this respect, the cells in question are somehow analogous to glial cells which support and nurse neurons. It seems possible to postulate that certain specific substances such as S-100 might be required for the nurse cells of cells with such particularly elaborate functions as neurons and lymphocytes.

Acknowledgment. We wish to thank Dr. Nakajima, Pathology Division, National Cancer Center Research Institute for his advice and co-operation.

\section{REFERENCES}

Cocchia, D.: Immunocytochemical localization of S-100 protein in the brain of adult rat. Cell Tiss. Res. 214: 529-540 (1981).

Cocchia, D. and N. Miani : Immunocytochemical localization of the brain-specific S-100 protein in the pituitary gland of adult rat. J. Neurocytol. 9: 771-782 (1980).

Cocchia, D. and F. Michetti : S-100 antigen in satellite cells of the adrenal medulla and the superior cervical ganglion of the rat. An immunochemical and immunocytochemical study. Cell Tiss. Res. 215: 103-112 (1981).

Cocchia, D., F. Michetti and R. Donato: Immunochemical and Immunocytochemical localization of S-100 antigen in normal human skin. Nature 294: 85-87 (1981).

Heusermann, U., K.-H. Zurborn, L. Schroeder and H. J. Stutte: The origin of the dendritic reticulum cell. An experimental enzyme-histochemical and electron microscopic study on the rabbit spleen. Cell Tiss. Res. 209: 279-294 (1980). 
Isobe, T. and T. Okuyama : The amino-acid sequence of S-100 protein (PAP I-b protein) and its relation to the calcium-binding proteins. Eur. J. Biochem. 89: 379-388 (1978).

Iwanaga, T., T. Fujita, Y. Takahashi and T. Nakajima: Meissner's and Pacinian corpuscles as studied by immunohistochemistry for S-100 protein, neuron-specific enolase and neurofilament protein. Neurosci. Lett. 31: 117-121 (1982).

Kashimura, M.: SEM studies of bone marrow. In: (ed. by) O. Johari: Scanning electron microscopy/ 1982. SEM Inc., Chicago, 1982, in press.

Kondo, H., T. Iwanaga and T. Nakajima : Immunocytochemical study on the localization of neuron-specific enolase and S-100 protein in the carotid body of rats. Cell Tiss. Res. (1982, in press).

Ludwin, S. K., J. C. Kosek and L. F. Eng: The topographical distribution of S-100 and GFA proteins in the adult rat brain: An immunohistochemical study using horseradish peroxidaselabelled antibodies. J. comp. Neurol. 165: 197-208 (1976).

Moore, B. W.: A soluble protein characteristic of the nervous system Biochem. biophys. Res. Commun. 19: 739-744 (1965).

Nakajima, T., H. Yamaguchi and K. Takahashi : S 100 protein in folliculostellate cells of the rat pituitary anterior lobe. Brain Res. 191: 523-531 (1980).

Nakajima, T., Y. Sato, S. Watanabe, Y. Shimosato, K. Ishihara and T. Isobe : Immunoelectron microscopical demonstration of S-100 protein in epidermal Langerhans cell. Biomed. Res. 3: 226-231 (1982a).

Nakajima, T., S. Watanabe, Y. Sato, Y. Shimosato, M. Motoi and K. Lennert: S-100 protein in Langerhans cells, interdigitating reticulum cells and histiocytosis X cells. Gann 73: 429-432 (1982b).

Nakajima, T., S. Watanabe, Y. Sato, T. Kameya, T. Hirota and Y. Shimosato: Diagnostic application of S-100 protein in various human tumors: an immunoperoxidase study of S-100 protein distribution in normal and neoplastic tissues. Amer. J. Surg. Pathol. (1982c, in press).

Stefansson, K., R. L. Wollmann and B. W. Moore: Distribution of S-100 protein outside the central nervous system. Brain Res. 234: 309-317 (1982a).

Stefansson, K., R. L. Wollmann, B. W. Moore and B. G. W. Arnason: S-100 protein in human chondrocytes. Nature 295: 63-64 (1982b).

Sternberger, L. A.: Immunocytochemistry. Prentice Hall Inc., Englewoods Cliffs, New Jersey, 1974.

Weiss, L.: The haemopoietic microenvironment of bone marrow: an ultrastructural study of the interactions of blood cells, stroma and blood vessels. In: (ed. by) R. Porter, M. O'Connor and J. Whelan: Blood cells and vessel walls: functional interactions. Excerpta Medica, Amsterdam, 1980 (p. 3-19).

Zomzely-Neurath, C. E. and W. A. Walker: Nervous system-specific proteins: 14-3-2 protein, neuron-specific enolase, and S-100 protein. In: (ed. by) R. A. Bradshaw and D. M. Schneider: Proteins of the nervous system, 2nd ed. Raven Press, New York, 1980 (p. 1-57).

\author{
岩永敏彦 \\ 干951 新潟市旭町通 1 \\ 新潟大学医学部 \\ 第三解剖学教室
}

Dr. Toshihiko Iw AN AG A

Department of Anatomy

Niigata University School of Medicine

Asahimachi, Niigata

951 Japan 